\title{
AKIBAT HUKUM PELAKSANAAN PETUNJUK JAKSA YANG DILAKUKAN OLEH JAKSA TERHADAP PASAL 385 KUHP
}

\author{
Arief Pratomo \\ Brigade Mobil Kepolisian Daerah Sumatera Utara \\ Jl. K.H. Wahid Hasyim No. 3i, Medan - Sumatera Utara \\ Email: ariefpratomo@gmail.com
}

\begin{abstract}
Abstrak
Tanah adalah sebagai sebagai salah satu sumber kehidupan yang sangat manusiawi sehingga tidak mengherankan bahwa setiap manusia ingin memiliki atau mengendalikannya yang mengakibatkan berbagai masalah pertanahan atau konflik tanah di Indonesia. Masalahmasalah pertanahan ini kadang-kadang juga mengarah pada kejahatan terhadap tanah yang seringkali dapat menyebabkan perselisihan antar individu. Hal ini lebih dikarenakan ketersediaan lahan yang tersedia dan jumlahnya terbatas tidak sebanding dengan kebutuhan manusia, semakin hari semakin tinggi nilai pemenuhan penggunaan lahan. Penelitian yang dilakukan adalah penelitian deskriptif dengan metode pendekatan hukum normatif (yuridis normatif) yang dilakukan dengan cara studi literatur. Alat pengumpulan data yang digunakan dalam penelitian ini adalah data dalam bentuk studi dokumen dan pencarian literatur. Teori yang digunakan dalam penelitian ini adalah teori Tanggung Jawab Pidana, Teori Kepastian Hukum dan Teori Keadilan. Berdasarkan hasil penelitian dapat dipahami bahwa dasar untuk penerbitan instruksi atau kebijakan kejaksaan pada institusi kejaksaan adalah Undang-Undang Nomor 16 tahun 2004 tentang Kantor Kejaksaan Republik Indonesia dan Kitab UndangUndang Hukum Acara Pidana yang terkandung dalam Pasal 110.
\end{abstract}

\section{Kata Kunci: Akibat Hukum, Petunjuk, Jaksa}

\section{Abstract}

Land is very human life so it is not surprising that every human being wants to possess or control it which results in various land problems or land conflicts in Indonesia. These land issues sometimes also lead to crimes against land which can often lead to disputes between individuals. This is more due to the availability of land that is available and limited in number is not comparable to human needs, the more days the higher the value of fulfillment of land use. The research conducted was descriptive research with normative legal approach method (normative juridical) carried out by means of literature study. The data collection tool used in this study is data in the form of document studies and literature searches. The theory used in this research is the theory of Criminal Liability, Theory of Legal Certainty and Justice Theory. Based on the results of the study it was understood that the basis for the issuance of the attorney's instructions or policies on the prosecutor's institution was Law No. 16 of 2004 concerning the Prosecutor's Office of the Republic of Indonesia and the Criminal Procedure Code contained in article 110.

Keywords: Legal Consequent, Indication, Prosecutor

\section{PENDAHULUAN}

Ciri dari negara adalah adanya sebuah konstitusi yang hidup di tengah- tengah masyarakat (M. Arsyad Sanusi, 2011, h. 587). Indonesia adalah Negara hukum, hal ini telah 
Akibat Hukum Pelaksanaan...(Arief Pratomo) DOI: https://doi.org/10.30596/dll.v3i2.3156

diatur pada Pasal 1 ayat 3 Undang-Undang Dasar Negara Republik Indonesia tahun 1945 yang telah menjadi pedoman dasar sistem Negara Republik Indoesia.

Sistem tersebut yang melatarbelakangi kehidupan setiap lapisan masyarakat yang ada, dimana sistem tersebut memiliki sifat yang memaksa dan terdiri atas beberapa aturan yang harus dipatuhi, aturan tersebut meliputi elemen tentang bagaimana sistem masyarakat untuk bernegara, bagaimana masyarakat berperilaku untuk membedakan mana yang boleh dan tidak boleh dilakukan, adapula sistem yang mengatur dimana masyarakat berhubungan dengan masyarakat lainnya ataupun dengan suatu lembaga dan badan hukum, seperti itulah sedikit ulasan tentang sistem Negara hukum yang ada di Indonesia

Permasalahan di bidang hukum seolah menjadi salah satu persoalan yang tidak pernah surut dalam kehidupan masyarakat, berbangsa, dan bernegara. Seiring meningkatnya permasalahan di bidang hukum maka meningkat pula kajian yuridis yang bertujuan menggali informasi terkait berbagai masalah dari perspektif hukum dan perundang-undangan yang ada.

Negara Indonesia merupakan suatu negara yang susunan kehidupan rakyatnya termasuk perekonomiannya masih bercorak agraris, bumi, air dan ruang angkasa mempunyai fungsi yang amat penting untuk membangun masyarakat yang adil dan makmur. Bidang yang dimaksud dalam hal ini agar dapat memberikan keadilan dan kemakmuran bagi masyarakat adalah bidang pertanahan. Tanah merupakan suatu sumber daya alam yang sangat penting untuk kelangsungan hidup manusia.

Hubungan manusia dengan tanah bukan hanya sekedar tempat hidup akan tetapi lebih dari itu tanah merupakan tempat dimana manusia dapat hidup, tumbuh dan berkembang. Tanah sudah menjadi sumber bagi segala kepentingan hidup manusia dan menjadi bahan komoditas yang umumnya berada dan dikuasai serta dimiliki oleh orang perorangan (Rahmat Ramadhani, 2019).

Di dalam prosesnya, untuk dapat tercapainya pemenuhan atas tanah yang adil dan makmur bagi masyarakat maka pemerintah dalam melaksanakan kebijakannya kerap kali harus melandaskan hukumnya terhadap Pasal 33 ayat 3 Undang-Undang Dasar 1945 "Bumi dan air dan kekayaan alam yang terkandung didalamnya dikuasai oleh negara dan dipergunakan untuk sebesar-besarnya kemakmuran rakyat" dan diperjelas kembali di dalam Undang-Undang Nomor 5 Tahun 1960 tentang Pokok Agraria (UUPA) Pasal 1 ayat 2 yang berbunyi: "Seluruh bumi, air dan ruang angkasa, termasuk kekayaan alam yang terkandung di dalamnya dalam wilayah 2 Republik Indonesia sebagai karunia Tuhan Yang Maha Esa adalah bumi, air dan ruang angkasa bangsa Indonesia merupakan kekayaan nasional”.

Begitu pentingnya tanah bagi kehidupan manusia sehingga tidak mengherankan apabila setiap manusia ingin memiliki atau menguasainya yang berakibat timbulnya berbagai masalah pertanahan atau konflik pertanahan di Indonesia. Permasalahan tanah ini terkadang juga menimbulkan kejahatan terhadap tanah yang kerap kali dapat menimbulkan perselisihan antar perorangan.

Hal ini lebih disebabkan oleh karena ketersediaan tanah yang ada dan terbatas jumlahnya tidak sebanding dengan kebutuhan manusia yang semakin hari semakin tinggi nilai 
Jurnal Ilmu Hukum

FAKULTAS HUKUM UMSU
Akibat Hukum Pelaksanaan...(Arief Pratomo)

Volume 3 Nomor 2, Juli-Desember 2018, 119-130 DOI: https://doi.org/10.30596/dll.v3i2.3156

pemenuhan akan penggunaan tanah tersebut. Hal ini menimbulkan terjadinya ketimpangan sosial/ ketidakseimbangan di dalam pemenuhannya sehingga kejahatan terhadap tanah dapat sering terjadi di tengah-tengah kehidupan masyarakat. Selain itu, Kohlberg yang dikutip oleh Noach menyatakan bahwa perilaku jahat manusia itu ditentukan oleh beberapa factor :

1. Faktor pendorong, keinginan yang datang dari dalam diri manusia sendiri yang menuntut untuk dipenuhi egoisme dan rangsangan yang datang dari luar

2. Faktor penghambat, kendali dari dalam diri sendiri (moral) dan kontrol dari masyarakat luar, ancaman dan hukuman dan lain-lain (Muhadar, 2006, h. 31).

Istilah kejahatan di bidang pertanahan sebenarnya bukanlah istilah baru dalam hukum pidana, tetapi merupakan istilah yang sama dengan kejahatan pada umumnya sebagaimana yang diatur dalam buku II KUHP. Hanya saja kebetulan istilah kejahatan di bidang pertanahan ini berhubungan dengan tanah atau pertanahan sebagai obyek atau salah satu unsur adanya kejahatan.

Adapun pasal-pasal dalam KUHP yang berhubungan dengan kejahatan pertanahan adalah sebagai berikut: 1. Kejahatan terhadap penyerobotan tanah diatur dalam Pasal 167 KUHP, 2. Kejahatan terhadap pemalsuan surat-surat yang masing-masing diatur dalam Pasal 263, 264, 266 dan 274 KUHP, 3. Kejahatan penggelapan terhadap hak atas barang tidak bergerak seperti tanah, rumah dan sawah. Kejahatan ini biasa disebut kejahatan yang diatur dalam Pasal 385 KUHP.

Tinjauan yuridis yang menggunakan dasar-dasar hukum, teori dan perundang-undangan dalam mengkaji suatu masalah, menjadi sangat penting dalam menemukan solusi hukum atas suatu masalah yang hendak dikaji. Salah satu permasalahan di bidang hukum yang sudah banyak dikaji secara yuridis yaitu dalam tindak pidana, khususnya menyangkut ketidakadilan dan kepastian hukum.

Penyelesaian suatu perkara pidana sering kali menimbulkan polemik atau ketidakpuasan di kalangan pencari keadilan karena penegak hukum di nilai merugikan salah satu pihak yang berperkara. Demikian hal nya dalam konteks kepastian hukum, yang sering kali memunculkan permasalahan akibat lemahnya peraturan perundang-undangan yang ada dalam mengatur suatu penyelesaian masalah hukum khususnya dalam perkara tindak pidana.

Salah satu permasalahan yang sering terjadi dalam kehidupan bermasyarakat dalam perspektif tindak pidana adalah permasalahan yang menyangkut dengan tanah. Tanah merupakan salah satu kebutuhan hidup manusia yang sangat mendasar, dapat dikatakan hampir kegiatan hidup manusia baik secara langsung maupun tidak langsung selalu berhubungan dengan tanah.

Zaman era reformasi ini, masalah-masalah yang berkaitan dengan perbuatanperbuatan pidana sering kali disalah artikan oleh bebagai kalangan masarakat yang belum mengerti akan arti daripada reformasi itu sendiri. Dapat dilihat dalam kasat mata masih banyak masyarakat yang dapat dipengaruhi oleh orang-orang tertentu untuk berbuat sesuatu atas suatu permasalahan yang menurut pandangan mereka perberbuatan tersebut adalah benar, akan tetapi nyatanya perbuatan tersebut mempunyai dampak yang negatif bagi diri sendiri maupun 
Jurnal Ilmu Hukum FAKULTAS HUKUM UMSU
Akibat Hukum Pelaksanaan...(Arief Pratomo) DOI: https://doi.org/10.30596/dll.v3i2.3156

masyarakat pada umumnya khususna bagi Bangsa dan Negara karena perbuatan mereka adalah perbuatan-perbuatan yang merupakan kejahatan perampasan hak-hak atas tanah milik orang lain.

Di dalam sejarah, tanah merupakan faktor yang paling utama dalam menentukan produksi setiap fase peradaban. Tanah tidak hanya memiliki nilai ekonomis tinggi, tetapi juga nilai filosofis, politik, sosial, dan kultural. Tak mengherankan jika tanah menjadi harta istimewa yang tak henti-henti nya memicu berbagai masalah sosial yang kompleks dan rumit.

Jumlah dan luas tanah yang tidak seimbang dengan kebutuhan masyarakat akan melahirkan kompetisi antar sesama manusia untuk memperoleh tanah hal ini mengakibatkan banyak timbulnya konflik agraria. Seperti kita ketahui, tanah merupakan salah satu aset yang sangat berharga, mengingat harga tanah yang sangat stabil dan terus naik seiring dengan perkembangan zaman.

Penyerobotan tanah bukan lah hal baru yang terjadi di Indonesia. Kata penyerobotan sendiri dapat diartikan dengan perbuatan mengambil hak atau harta dengan sewenang-wenang atau dengan tidak mengindahkan hukum dan aturan, seperti menempati tanah atau rumah orang lain, yang bukan merupakan hak nya. Tindakan penyerobotan tanah secara tidak sah merupakan perbuatan yang melawan hukum, yang dapat digolongkan sebagai suatu tindak pidana.

Tindak pidana penyerobotan tanah oleh seseorang atau sekelompok orang terhadap tanah milik orang lain dapat diartikan sebagai perbuatan menguasai, menduduki, atau mengambil alih tanah milik orang lain secara melawan hukum, melawan hak, atau melanggar peraturan hukum yang berlaku. Karena itu, perbuatan tersebut dapat digugat menurut hukum perdata ataupun dituntut menurut hukum pidana.

Sesuai ketentuan Pasal 385 Kitab Undang-Undang Hukum Pidana (KUHP) menyatakan bahwa seseorang yang secara melawan hukum, menjual, menukarkan tanah yang bukan miliknya kepada pihak lain dan memperoleh keuntungan atas perbuatannya tersebut, diancam pidana penjara paling lama empat tahun.

Dalam hal ini unsur yang harus dipenuhi yaitu adanya unsur "menguntungkan diri sendiri atau orang lain secara melawan hukum, menjual, menukarkan”, yang berarti perbuatan seseorang yang menjual/menukarkan tanah yang bukan miliknya kepada pihak lain dan memperoleh keuntungan atas perbuatannya tersebut. Berdasarkan latar belakang yang telah diuraikan diatas, maka permasalahan pokok yang menjadi rumusan masalah dalam penelitian ini, adalah apakah akibat hukum pelaksanaan petunjuk jaksa yang dilakukan oleh jaksa terhadap Pasal 385 KUHP.

\section{METODE PENELITIAN}

Jenis penelitian yang dipergunakan dalam penelitian ini adalah penelitian hukum normatif. Penelitian hukum normatif adalah penelitian yang dilakukan dengan cara meneliti bahan pustaka (data sekunder) atau penelitian hukum kepustakaan (Ediwarman, 2009, h. 24). Penelitian hukum normatif merupakan suatu prosedur penelitian ilmiah untuk menemukan kebenaran berdasarkan logika keilmuan hukum dari sisi normatifnya. Logika keilmuan yang 
Jurnal Ilmu Hukum

FAKULTAS HUKUM UMSU
Akibat Hukum Pelaksanaan...(Arief Pratomo)

Volume 3 Nomor 2, Juli-Desember 2018, 119-130 DOI: https://doi.org/10.30596/dll.v3i2.3156

sering dalam penelitian hukum normatif yaitu ilmu hukum yang objeknya hukum itu sendiri (Jhonny Ibrahim, 2006, h. 57). Penelitian hukum normatif terdiri dari (Ediwarman, 2009, h. $30)$.

Data pokok dalam penelitian ini adalah data sekunder, yaitu data atau informasi hasil penelaahan dokumen penelitian serupa pernah dilakukan sebelumnya, bahan kepustakaan seperti buku-buku, literatur, koran, majalah, jurnal ataupun arsip-arsip yang sesuai dengan penelitian yang akan di bahas yang meliputi Bahan hukum primer yakni bahan-bahan yang terdiri dari peraturan perundang-undangan (Jhoni Ibrahim. 2006, h. 295). Misalnya Kitab Undang-Undang Hukum Pidana (KUHP), Kitab Undang-Undang Hukum Acara Pidana (KUHAP).

Penelitian ini bersifat deskriptif analisis (Bambang Waluyo, 1996, h. 8). Penelitian yang bersifat deskriptif analisis merupakan suatu penelitian yang mengambarkan, menelaah, menjelaskan dan menganalisis suatu peraturan hokum. Penelitian ini merupakan suatu kegiatan ilmiah yang didasarkan pada metode, sistematika dan pemikiran tertentu yang bertujuan untuk mempelajari suatu hukum tertentu dengan jalan menganalisanya (Soerjono Soekamto dan Sri Mamudji 1995, h. 43).

\section{PEMBAHASAN}

\section{Akibat Hukum Pelaksanaan Petunjuk Jaksa Yang Dilakukan Oleh Jaksa Terhadap Pasal 385 KUHP}

\section{Kekuatan Hukum Petujuk Jaksa Dalam Hukum Pidana Indonesia}

Secara yuridis kekuatan hukum petunjuk jaksa setara dengan undang undang, karena petunjuk jaksa diatur dalam dalam Undang-Undang Nomor 16 tahun 2004 tentang Kejaksaan Republik Indonesia sebagai perubahan atas Undang-Undang Nomor 5 Tahun 1991 tentang Kejaksaan Republik Indonesia (Soerjono Soekamto dan Sri Mamudji, 1995, h. 22). Namun dalam hal penambahan unsur pasal, Kejaksaan tiak memiliki kewenangan untuk itu, karena dalam pemahaman penulis, unsur pasal bersifat baku dan tidak bisa di ubah kecuali kalimat dalam pasal tersebut berubah.

Lain halnya dengan penambahan Pasal pada tersangka, hal ini mungkin dapat terjadi karena kejaksaan memiliki kewenangna akan hal itu. Penyerobotan tanah adalah pendudukan atas tanah yang sudah dipunyai oleh orang lain. Penyerobotan tanah diatur dalam KUHP dan Perppu 51/1960, dimana diatur larangan memakai tanah tanpa izin yang berhak atau kuasanya yang sah. Pihak yang berhak atas tanah tersebut dapat melakukan langkah hukum pidana dan perdata untuk menjerat perbuatan kepala desa yang membantu proses penyerobotan tanah.

Jika ingin menjerat secara hukum pidana, maka dapat dikenakan pidana yang terdapat dalam KUHP maupun dalam Perppu 51/1960. Perppu 51/1960 misalnya yang mengatur mengenai larangan memakai tanah tanpa izin yang berhak atau kuasanya yang sah Memakai tanah adalah menduduki, mengerjakan dan/atau mengenai sebidang tanah atau mempunyai tanaman atau bangunan di atasnya, dengan tidak dipersoalkan apakah bangunan itu dipergunakan sendiri atau tidak. Memakai tanah tanpa izin yang berhak atau kuasanya yang 
Jurnal Ilmu Hukum

FAKULTAS HUKUM UMSU
Akibat Hukum Pelaksanaan...(Arief Pratomo)

Volume 3 Nomor 2, Juli-Desember 2018, 119-130 DOI: https://doi.org/10.30596/dll.v3i2.3156

sah adalah perbuatan yang dilarang dan diancam hukuman pidana kurungan dan/atau denda

Pidana ini juga berlaku bagi orang yang memberi bantuan dengan cara apapun juga untuk melakukan perbuatan memakai tanah tanpa izin pihak yang berhak atas tanah tersebut. Oleh karena itu, kepala desa yang memberikan bantuan dalam penyerobotan tanah (pendudukan tanah oleh orang lain), dapat dipidana juga.

Sisi lain dalam hukum perdata, jika pihak yang berhak atas tanah tersebut merasa dirugikan atas penyerobotan tanah, maka langkah hukum yang dapat ditempuh adalah mengajukan gugatan perdata atas dasar perbuatan melawan hukum Penjelasan lebih lanjut dapat Anda simak dalam ulasan di bawah ini.

Mengenai penyerobotan tanah, dapat Anda lihat pengaturannya dalam Kitab UndangUndang Hukum Pidana (KUHP) dan Peraturan Pemerintah Pengganti Undang-Undang Nomor 51 Tahun 1960 tentang Larangan Pemakaian Tanah Tanpa Izin yang Berhak atau Kuasanya (Perppu 51/1960).

Secara umum, pengaturan penyerobotan yang diatur dalam KUHP merupakan penyerobotan tanah terhadap hak pakai. Penyerobotan tanah terhadap hak atas tanah dalam artian lebih luas diatur dalam Perppu 51/1960.

Menurut sebuah jurnal yang disusun oleh Kurnia Warman dan Syofiarti dalam sebuah jurnal yang disusunnya Pola Penyelesaian Sengketa Tanah Ulayat di Sumatera Barat (Sengkta Antara Masyarakat Vs Pemerintah), yang disebut dengan penyerobotan tanah adalah pendudukan tanah yang sudah dipunyai oleh orang lain. Yang dimaksud dengan pendudukan menurut Kamus Besar Bahasa Indonesia adalah proses, cara, perbuatan menduduki (merebut dan menguasai) suatu daerah dan sebagainya. Jadi penyerobotan tanah tersebut dapat dikatakan sebagai perbuatan merebut dan menguasai atau menduduki tanah yang dimiliki oleh orang lain.

Soesilo menambahkan, supaya dapat dikenakan pasal ini, maka terdakwa harus nyata berbuat hal-hal sebagai berikut:

\section{Menurut KUHP}

Perbuatan penyerobotan tanah tidak secara tegas dirumuskan dalam KUHP, namun Pasal 385 KUHP (R. Soesilo) mengatur tentang kejahatan yang berkaitan langsung dengan kepemilikan tanah;

Barang siapa dengan maksud hendak menguntungkan diri sendiri atau orang lain dengan melawan hak menjual, menukar, atau menjadikan tanggungan utang sesuatu hak Rakyat dalam memakai tanah Pemerintah atau tanah partikulir atau sesuatu rumah, pekerjaan, tanaman atau bibit di tanah tempat orang menjalankan hak Rakyat memakai tanah itu, sedang diketahuinya bahwa orang lain yang berhak atau turut berhak atas barang itu.

R. Soesilo dan bukunya Kitab Undang-Undang Hukum Pidana (KHUP) Serta Komentar-Komenternya Lengkap Pasal Demi Pasal (h. 266-267) menjelaskan bahwa kejahatan-kejahatan yang terdapat dalam pasal ini disebut dengan kejahatan Stellionnaat yang 
Jurnal Ilmu Hukum

FAKULTAS HUKUM UMSU
Akibat Hukum Pelaksanaan...(Arief Pratomo)

Volume 3 Nomor 2, Juli-Desember 2018, 119-130 DOI: https://doi.org/10.30596/dll.v3i2.3156

berarti penggelapan hak atas barang-barang yang tidak bergerak, barang-barang yang tidak bergerak misalnya tanah, sawah, gedung, dan lain-lain. Lebih lanjut:

a) Terdakwa ada maksud untuk menguntungkan diri sendiri atau orang lain dengan melawan hak (secara tidak sah);

b) Terdakwa telah menjual, menukar atau membebani dengan credit verband hak pakai bumiputera atas tanah milik negara atau tanah milik partikulir, atau gedung, pekerjaan, tanaman atau taburan di atas tanah hak pakai bumiputera;

c) Terdakwa mengetahui, bahwa yang berhak atau ikut berhak di situ adalah orang lain;

d) Terdakwa tidak memberitahukan kepada pihak lain, bahwa di situ ada credit verbandnya;

e) Terdakwa tidak memberitahukan kepada pihak lain, bahwa tanah itu sudah digadaikan;

f) Terdakwa telah menggadaikan atau menyewakan tanah orang lain;

g) Terdakwa telah menjual atau menukarkan tanah yang sedang digadaikan pada orang lain dengan tidak memberitahukan tentang hal itu kepada pihak yang berkepentingan.

h) Terdakwa telah menyewakan tanah buat selama suatu masa, sedang diketahuinya, bahwa tanah itu sebelumnya telah disewakan kepada orang lain.

Hak pakai bumiputera atas tanah yaitu pada umumnya tanah di Indonesia adalah milik negara, penduduk yang biasa kita sebut pemilik tanah ini sebenarnya hanya mempunyai hak untuk memakai tanah itu saja, karena pemiliknya adalah negara. Hak itu kita sebut hak pakai bumiputera atas tanah.

Credit verband adalah penduduk yang mempunyai hak pakai bumiputera atas suatu tanah itu, dapat pinjam uang dari Bank Rakyat dengan memakai tanah tersebut sebagai jaminannya (borg). Perjanjian semacam ini dinamakan credit verband, semacam gadai tanah. Jadi menurut Pasal 385 ayat 1 KUHP, jika seseorang dengan maksud untuk menguntungkan diri sendiri atau orang lain dengan melawan hak (secara tidak sah) menjual, menukar, atau menjadikan tanggungan utang hak orang lain untuk memakai tanah negara, maka dapat dihukum penjara selama 4 (empat) tahun penjara. Melihat pada ketentuan di atas, memang tidak ada yang secara eksplisit melarang pendudukan tanah orang lain (hak untuk memakai tanah negara).

\section{Menurut PERPPU Nomor 51 Tahun 1960 Tentang Larangan Pemakaian Tanah Tanpa Izin yang Berhak atau Kuasanya}

Mengenai menduduki tanah orang lain, dapat dilihat dalam Peraturan Pemerintah Pengganti Undang-Undang Nomor 51 Tahun 1960 tentang Larangan Pemakaian Tanah Tanpa Izin yang Berhak atau Kuasanya (Perppu 51/1960). Perppu 51/1960 mengatur mengenai larangan memakai tanah tanpa izin yang berhak atau kuasanya yang sah.

Memakai tanah ialah menduduki, mengerjakan dan/atau mengenai sebidang tanah atau mempunyai tanaman atau bangunan di atasnya, dengan tidak dipersoalkan apakah bangunan itu dipergunakan sendiri atau tidak. Memakai tanah tanpa izin yang berhak atau kuasanya yang sah adalah perbuatan yang dilarang dan diancam hukuman pidana dengan hukuman 
Jurnal Ilmu Hukum

FAKULTAS HUKUM UMSU
Akibat Hukum Pelaksanaan...(Arief Pratomo)

Volume 3 Nomor 2, Juli-Desember 2018, 119-130 DOI: https://doi.org/10.30596/dll.v3i2.3156

kurungan selama-lamanya 3 (tiga) bulan dan/atau denda sebanyak-sebanyaknya Rp. 5.000.

Pidana ini juga berlaku bagi orang yang memberi bantuan dengan cara apapun juga untuk melakukan perbuatan memakai tanah tanpa izin pihak yang berhak atas tanah tersebut. Oleh karena itu, kepala desa yang memberikan bantuan dalam penyerobotan tanah (pendudukan tanah oleh orang lain), dapat dipidana juga.

Selain dalam Perppu 51/1960, kepala desa tersebut bisa juga diancam pidana berdasarkan KUHP. Kepala Desa merupakan orang yang bertugas sebagai penyelenggara pemerintahan desa. Perbuatan penyerobotan tanah yang dilakukan dapat juga dikenai Pasal 424 KUHP, yang berbunyi: Pegawai negeri yang dengan maksud akan menguntungkan dirinya atau orang lain dengan melawan hak serta dengan sewenang-wenang memakai kekuasaannya menggunakan tanah Pemerintah yang dikuasai dengan hak Bumiputera, dihukum penjara selama-lamanya enam tahun.

Pegawai negeri atau ambtenaar menurut R.Soesilo adalah orang yang diangkat oleh kekuasaan umum menjadi pejabat umum untuk menjalankan sebagian dari tugas pemerintahan atau bagian-bagiannya. Unsur-unsur yang termasuk di sini adalah:

a) Pengangkatan oleh instansi umum;

b) Memangku jabatan umum, dan

c) Melakukan sebagian dari tugas pemerintahan atau bagian-bagiannya.

Kepala desa dan para pegawainya termasuk salah satu dari golongan ambtenaar atau pegawai negeri. Lebih lanjut R. Soesilo menjelaskan, supaya dapat dihukum, maka pegawai negeri tersebut harus melakukan perbuatan tersebut dalam melakukan jabatannya. Perbuatan Penyerobotan Tanah Menurut Hukum Perdata Sedangkan menurut hukum perdata, orangorang yang melakukan penyerobotan tanah dapat dijerat dengan tuduhan perbuatan melawan hukum. Hal ini bisa dilihat bahwa dalam kasus penyerobotan tanah ada pihak yang dirugikan dan menuntut ganti rugi atas kerugian yang dialami. Selain itu, penyerobotan tanah juga merupakan perbuatan dimana seseorang secara tanpa hak masuk ke tanah.

Perbuatan Melawan Hukum (onrechtmatige daad) dalam konteks hukum perdata diatur dalam Pasal 1365 Kitab Undang-Undang Hukum Perdata atau Burgerlijk Wetboek (BW), dalam Buku III BW, pada bagian 'Tentang perikatan-perikatan yang dilahirkan demi UndangUndang' yang berbunyi “Tiap perbuatan melanggar hukum, yang membawa kerugian kepada orang lain, mewajibkan orang yang karena salahnya menerbitkan kerugian itu, mengganti kerugian tersebut".

Seperti yang sering dijelaskan dalam beberapa artikel sebelumnya, salah satunya dalam artikel Merasa Dirugikan Tetangga yang Menyetel Musik Keras-keras, dikatakan antara lain Mariam Darus Badrulzaman dalam bukunya "KUH Perdata Buku III Hukum Perikatan Dengan Penjelasan", seperti dikutip Rosa Agustina dalam buku Perbuatan Melawan Hukum (hal. 36) yang menjabarkan unsur-unsur perbuatan melawan hukum sebagai berikut:

a) Harus ada perbuatan (positif maupun negatif);

b) Perbuatan itu harus melawan hukum;

c) Ada kerugian; 
Akibat Hukum Pelaksanaan...(Arief Pratomo)

d) Ada hubungan sebab akibat antara perbuatan melawan hukum itu dengan kerugian;

e) Ada kesalahan.

Menurut (Rosa Agustina, 117), dalam menentukan suatu perbuatan dapat dikualifisir sebagai melawan hukum, diperlukan 4 syarat:

a) Bertentangan dengan kewajiban hukum si pelaku

b) Bertentangan dengan hak subjektif orang lain

c) Bertentangan dengan kesusilaan

d) Bertentangan dengan kepatutan, ketelitian dan kehati-hatian.

Untuk dapat menjerat perbuatan kepala desa yang membantu proses penyerobotan tanah, pihak yang berhak atas tanah tersebut dapat melakukan langkah hukum pidana dan perdata. Jika ingin menjerat dengan pidana, maka dapat dikenakan pidana yang mengatur mengenai penyerobotan tanah baik yang terdapat dalam KUHP maupun dalam PERPPU No. 51 Tahun 1960 Tentang Larangan Pemakaian Tanah Tanpa Izin yang Berhak atau Kuasanya.

Di sisi lain dalam hukum perdata, jika pihak yang berhak atas tanah tersebut merasa dirugikan atas penyerobotan tanah, maka langkah hukum yang dapat ditempuh adalah mengajukan gugatan perdata atas dasar perbuatan melawan hukum.

\section{Akibat Hukum Petunjuk Jaksa Terhadap Penambahan Unsur Pasal 385 KUHP}

Di dalam hal akibat hukum petunjuk jaksa terhadap penambahan unsur pasal pada pasal 385 Kitab Undang-Undang Hukum Pidana di nilai tidak memiliki kekuatan, dikarenakan pemahaman penulis terkait dengan penambahan unsur pasal itu tidak ada baik itu dalam Kitab Undnag-Undang Hukum Acara Pidana (KUHAP) dan atau dalam Secara yuridis kekuatan hukum petunjuk jaksa setara dengan undang undang, karena petunjuk jaksa diatur dalam dalam Undang-Undang Nomor 16 tahun 2004 Tentang Kejaksaan Republik Indonesia sebagai perubahan atas Undang-Undang Nomor 5 Tahun 1991 Tentang Kejaksaan Republik Indonesia. yang ada hanyalah penambahan pasal dan pengurangan unsur pasal, hal ini di karenakan unsur yang ada di dalam pasal per pasal bersifat baku.

\section{Formulasi Kedepan Dalam Menghadapi Pelaksanoaan Petunjuk}

Pakar Hukum Pidana Saint Louis University School of Law, Berkeley, Amerika Serikat, Stephen C. Thaman menjelaskan jaksa dan polisi dapat melakukan penyidikan bersama dalam sistem hukum pidana modern. Model ini dipergunakan di Inggris dan Amerika guna menyederhanakan proses dan mempersingkat waktu dari penyidikan hingga pelimpahan perkara ke pengadilan.

Di dalam kenyataan, Inggris tidak mempunyai jaksa sampai saat yang belum lama ini. Pada dasarnya, jaksa penuntut akan memutuskan menerima pemeriksaan dari polisi untuk melanjutkannya dengan penuntutan atau tidak," ujarnya dalam sidang yang dipimpin oleh Ketua MK Arief Hidayat tersebut.

Menyambung pernyataan Thaman, Andi Hamzah selaku ahli Pemohon lainnya, menjelaskan harus adanya penyusunan kembali KUHAP guna menyederhanakan sistem 
Jurnal Ilmu Hukum FAKULTAS HUKUM UMSU
Akibat Hukum Pelaksanaan...(Arief Pratomo) DOI: https://doi.org/10.30596/dll.v3i2.3156

seperti halnya negara lain. Ia mengungkapkan rancangan perubahan KUHAP sebaiknya disesuaikan dengan kemajuan teknologi. "Dengan kemajuan teknologi, harus ada perubahan perundang-undangan. KUHP Belanda dan KUHAP Belanda hampir tiap tahun diubah, tidak sama lagi dengan KUHP kita yang sekarang. Hampir tiap tahun diubah karena ada kemajuan teknologi yang harus diikuti oleh perundang-undangan. Jadi tidak ada P-19, tidak P-21, setelah perkara diserahkan kepada jaksa selesai sekarang P-21, tidak ada lagi hubungan antara penyidik dengan jaksa" paparnya.

Hak tersangka untuk diperiksa penyidik, dimajukan dan diadili di persidangan dalam hukum acara saat ini hanya berupa kata 'segera', maka dalam rancangan KUHAP diatur lebih limitatif, yakni pemeriksaan oleh penyidik dilakukan satu hari setelah ditangkap/ditahan. Penyerahan kepada penuntut umum adalah enam puluh hari (jika ditahan) dan sembilan puluh hari (jika tidak ditahan), sedangkan hak untuk segera diadili di persidangan adalah empat belas hari dan dapat diperpanjang selama empat belas hari.

Pemohon menilai keberadaan aturan tersebut dapat menghambat upaya Pemohon dalam menjaga dan menegakkan nilai-nilai konstitusionalisme dengan berperan aktif melakukan advokasi. Ketentuan Pasal 109 ayat 1 menyebabkan penyidikan dilakukan tanpa kontrol dan pengawasan penuntut umum karena tidak jelasnya kapan surat pemberitahuan dimulainya penyidikan diberitahukan kepada penuntut umum. Ketentuan Pasal 138 ayat 1 dan ayat 2 juga dinilai bersifat multitafsir, sehingga menimbulkan ketidakpastian hukum dan seringkali melanggar hak-hak konstitusional.

Perumusan Pasal 138 ayat 1 dan 2 tidak jelas dan membuka pemaknaan berbeda yaitu dapat dilakukan lebih dari satu kali atau berulang kali tanpa batas waktu sehingga menimbulkan situasi bolak-baliknya berkas antara penyidik dan penuntut umum. Ketentuan Pasal 139 tidak secara jelas memberikan jangka waktu dalam menentukan apakah berkas perkara yang ada tersebut layak atau tidak dilimpahkan ke pengadilan.

Di dalam Pasal 14 KUHAP tidak ada pencantuman yang tegas tentang kewenangan penuntut umum untuk melakukan suatu pemeriksaan tambahan. Hal ini berbeda jika melihat Pasal 30 ayat 1 huruf e yang secara jelas mencantumkan bahwa Kejaksaan mempunyai wewenang untuk melakukan pemeriksaan tambahan (diakses).

Kemudian dari pada itu yang harus dilakukan penyidik dalam menghadapi petunjuk jaksa adalah kordinasi aktif antara jaksa dengan penyidik, kordinasi aktif ini di anggap perlu sehingga terciptanya kondisi yang harmonis dalam melakukan penyidikan dan penuntutan. Jaksa dalam menerima berita acara pemeriksaan (BAP) tidak hanya sekedr menerima berkas dari penyidik, perlu adanya kordinasi aktif antara penyidik kepolisian Republik Indonesia dengan Penuntut Umum.

\section{KESIMPULAN DAN SARAN Kesimpulan}

Tindakan penyidik dalam menghadapi petunjuk jaksa adalah kordinasi aktif antara jaksa dengan penyidik, kordinasi aktif ini di anggap perlu sehingga terciptanya kondisi yang 
harmonis dalam melakukan penyidikan dan penuntutan. Jaksa dalam menerima berita acara pemeriksaan (BAP) tidak hanya sekedar menerima berkas dari penyidik, perlu adanya kordinasi aktif antara penyidik kepolisian Republik Indonesia dengan Penuntut Umum.

\section{Saran}

Diharapkan agar dengan adanya akibat hukum dari petunjuk jaksa yang dilakukan oleh Kejati Sumut sesuai dengan Pasal 385 KUHP, hal ini tidak terulang dalam tindak pidana yang sama ataupun menjadi acuan bagi penuntut umum lainnya menggunakan dalih kebijakan petunjuk sebagai alat untuk menambah unsur pasal dalam aturan hukum yang ada. 


\section{DAFTAR PUSTAKA}

Ali, Zainuddin. (2009). Metode Penelitian Hukum. Edisi 1 (satu), Cetakan Pertama. Jakarta: Sinar Grafika.

Amiruddin dan Asikin, Zainal. (2013). Pengantar Metode Penelitian Hukum. Edisi Satu, Cetakan Ketujuh. Jakarta: Rajawali Pers.

Ediwarman. (2009). Monograf Metode Penelitian Hukum. Edisi satu. Medan: Genta Publishing.

Ibrahim, Jhonny. (2006). Teori Dan Metedologi Penelitian Hukum Normatif, Jakarta: Pustaka Pelajar.

Ibrahim, Jhonny. (2006). Teori Dan Penelitian Hukum Normatif. Malang: Publishing.

Muhadar. (2006). Viktimisasi Kejahatan Di bidang Pertanahan. LaksBang PRESSindo: Yogyakarta.

Ramadhani, Rahmat. (2019). Eksistensi Hak Komunal Masyarakat Hukum Adat Dalam Pengadaan Tanah untuk Kepentingan Hukum. Jurnal Penelitian Hukum De Jure, Vol. 19, No. 1, 98.

Sanusi, Arsyad, M. (2011). Tebaran Pemikiran Hukum dan Konstitusi. Jakarta: Milestone

Soekamto, Soerjono., \&Mamudji, Sri. (1995). Penelitian Hukum Normatif Suatu Tinjauan Singkat. Jakarta: RajaGrafindo Persada.

Waluyo, Bambang. (1996). Penelitian Hukum Dalam Praktek. Jakarta: Sinar Grafika. 